\title{
Controlling the simultaneous production of laccase and lignin peroxidase from Streptomyces cinnamomensis by medium formulation
}

\author{
Debing Jing ${ }^{1,2^{*}}$ and Jinghua Wang ${ }^{3}$
}

\begin{abstract}
Background: Use of crude ligninase of bacterial origin is one of the most promising ways to improve the practical biodegradation of lignocellulosic biomass. However, lignin is composed of diverse monolignols with different abundance levels in different plant biomass and requires different proportions of ligninase to realize efficient degradation. To improve activity and reduce cost, the simultaneous submerged fermentation of laccase and lignin peroxidase (LiP) from a new bacterial strain, Streptomyces cinnamomensis, was studied by adopting formulation design, principal component analysis, regression analysis and unconstrained mathematical programming.

Results: The activities of laccase and LiP from S. cinnamomensis cultured with the optimal medium formulations were improved to be five to eight folders of their initial activities, and the measured laccase:LiP activity ratios reached $0.1,0.4$ and 1.7 when cultured on medium with formulations designed to produce laccase:LiP complexes with theoretical laccase:LiP activity ratios of 0.05 to $0.1,0.5$ to 1 and 1.1 to 2 .

Conclusion: Both the laccase and LiP activities and also the activity ratio of laccase to LiP could be controlled by the medium formulation as designed. Using a crude laccase-LiP complex with a specially designed laccase:LiP activity ratio has the potential to improve the degradation of various plant lignins composed of diverse monolignols with different abundance levels.
\end{abstract}

\section{Background}

Lignocellulose degradation is the central process for carbon recycling in land ecosystems [1]. As the key step in lignocellulose decay, lignin degradation, removal or modification is the rate-limiting step of carbon recycling $[1,2]$, and also the central issue for industrial utilization of plant biomass (for example, biofuel production from abundant and renewable lignocellulosic material) $[3,4]$. Compared with the lignocellulosic biomass degradation by fungi, in vitro treatment of such biomass by lignindegrading enzymes has a number of advantages, such as shorter incubation period without bacterial growth, reduced possibility of infection during large-scale microbe culture, lack of inhibitory effect of toxic byproducts (such as furfural) on bacterial or fungal mycelial growth, and improved reaction efficiency of bacterial enzymes at higher temperatures $[1,5]$. However, lack of

\footnotetext{
* Correspondence: jingdb1@hotmail.com

${ }^{1}$ College of Life Sciences, Capital Normal University, Beijing 100048, China Full list of author information is available at the end of the article
}

commercially available, robust, and inexpensive enzymes is a major barrier for the widespread application of ligninolytic enzymes in various industrial sectors $[5,6]$. To avoid the high costs associated with enzyme purification procedures, one of the most promising ways to promote lignin biodegradation is to use crude enzymes [5-8].

Lignin is composed of chemically distinct subunits or monolignols (such as $p$-hydroxyphenyl, guaiacyl, and syringyl) whose abundance or proportions vary among plant species, and lignins of different plant origins require different proportions of laccase (E.C. 1.10.3.2), lignin peroxidase (LiP; E.C. 1.11.1.14) or manganese peroxidase, (MnP; E.C. 1.11.1.13) to promote the efficiency of degradation $[2,3,9,10]$. Laccase is the most preferred ligninase enzyme [11], but can directly oxidize only phenolic lignin units [12-14], which usually comprise less than $10 \%$ of the total polymer content of natural lignin $[1,12]$. By contrast, LiP is the most effective oxidizer ligninase known to date, and is capable of catalyzing the
Ciomed Central

(c) 2012 Jing and Wang; licensee BioMed Central Ltd. This is an Open Access article distributed under the terms of the Creative Commons Attribution License (http://creativecommons.org/licenses/by/2.0), which permits unrestricted use, distribution, and reproduction in any medium, provided the original work is properly cited. 
oxidation of phenolic or non-phenolic compounds, aromatic amines, aromatic ethers, and polycyclic aromatic hydrocarbons $[13,14]$. Thus, a laccase-LiP complex can be expected to be more efficient at lignin degradation than either of the two ligninases alone, owing to their potential synergism [5,6]. Further, laccases of fungal origin have low activity and stability at alkaline $\mathrm{pH}$ range or at high temperature, whereas laccases of bacterial origin have higher activity and stability under the same conditions $[10,15]$. One of the most studied aerobic cellulolytic bacteria species, Streptomyces, can produce ligninase with promising application potential under extreme conditions of high temperatures or high $\mathrm{pH}$ ranges $[5,10,15]$.

Generally, strain selection or improvement by genetic modification, optimization of medium formulation, and fermentation conditions are the main options to improve enzyme activity and reduce production cost $[5,6,10,15]$. Compared with the high cost and uncertain results of genetic engineering, optimization of the medium formulation (including medium ingredients or composition, nutrient limitation, removal of potential toxic inducers) and culture conditions is a more dependable method in regulating the production of ligninolytic enzyme $[5,16]$. Carbon and nitrogen are the two most important components of the nutritional medium for any fermentation process $[17,18]$, thus modifying or altering either or both in the medium should provide a marked improvement in the production of extracellular ligninolytic enzymes $[10,18]$.

Currently, the most efficient method for large-scale fermentation is submerged fermentation ( $\mathrm{SmF}$; that is, an agitated liquid culture) [10]. Traditionally, production of ligninolytic enzyme by SmF usually has a higher production cost because the liquid media usually contains some relatively expensive constituents such as glucose, ammonium tartrate, nitriloacetic acid, $\mathrm{MgSO}_{4}, \mathrm{NaCl}$, $\mathrm{FeSO}_{4}, \mathrm{CoCl}_{2}$, and $\mathrm{ZnSO}_{4}$ [19]. To decrease production cost, a potential solution is to adopt less expensive natural substrates as opposed to a chemically defined medium [20]. Coffee pulp, wheat bran, and yeast extract have been shown to be excellent substrates (nitrogen sources) for Streptomyces psammoticus to produce laccase by either SmF [21] or solid-state fermentation (SSF) [7]. Urea and sawdust have been used as nitrogen and carbon sources for laccase production from Pycnoporus sanguineus by SSF [22] and Lentinula edodes by SmF [23], respectively.

In this study, we aimed to produce a high activity laccase-LiP complex from a new strain of Streptomyces cinnamomensis by SmF using low cost liquid medium composed of yeast extract, coffee pulp, wheat bran, sawdust and urea.

\section{Results and discussion}

\section{Principal component analysis}

Laccase and LiP were simultaneously produced from $S$. cinnamomensis by SmF (Table 1).

Following principal component analysis (PCA), four principal components of $F_{1}, F_{2}, F_{3}, F_{4}$ were calculated as shown in equations 1 to 4 below:

$$
\begin{aligned}
\mathrm{F}_{1} & =0.381+0.01778 \times(\text { yeast extract })+0.0792 \times(\text { coffee pulp }) \\
& +0.462 \times(\text { wheat bran })-0.920 \times(\text { sawdust })
\end{aligned}
$$

The explained variances in $\mathrm{F}_{1}, \mathrm{~F}_{2}, \mathrm{~F}_{3}, \mathrm{~F}_{4}$ were $28.649 \%$, $25.610 \%, 24.721 \%$ and $20.661 \%$ respectively, and their cumulative percentage of variance reached $99.641 \%$.

\section{Regression analysis and mathematical programming}

Using linear regression, two second-degree polynomial regression models of laccase and LiP activities were constructed with four principal components $\left(\mathrm{F}_{1}\right.$ to $\left.\mathrm{F}_{4}\right)$ as variables, as shown in equations 5 and 6 below:

$$
\begin{aligned}
& \text { Laccase }=0.01617+0.002399 \times \mathrm{F}_{2}-0.00337 \\
& \quad \times \mathrm{F}_{3}-0.00179 \times \mathrm{F}_{4}-0.00258 \times \mathrm{F}_{1}^{2}-0.00410(5) \\
& \quad \times \mathrm{F}_{2}^{2}-0.00460 \times \mathrm{F}_{3}^{2}-0.00313 \times \mathrm{F}_{4}^{2}(0.929,0.191) \\
& \mathrm{LiP}=0.106+0.02944 \times \mathrm{F}_{2}-0.0290 \\
& \quad \times \mathrm{F}_{3}+0.004978 \times \mathrm{F}_{4}-0.0144 \times \mathrm{F}_{1}^{2}-0.0470 \\
& \quad \times \mathrm{F}_{2}^{2}-0.00910 \times \mathrm{F}_{3}^{2}-0.0294 \times \mathrm{F}_{4}^{2}(0.978,0.108)
\end{aligned}
$$

Using unconstrained mathematical programming, the maximal enzyme activities and their corresponding solutions to principal components were calculated (Table 2). Based on the relationship between the principal component and the initial variables (yeast extract, coffee pulp, wheat bran and sawdust) presented in equations 2 to 4 , the optimal dosages to the five medium ingredients corresponding to the maximum laccase or LiP activity could also be calculated (Table 2).

\section{Design of verification experiment}

For ligninolytic enzyme production, the types and concentrations of the carbon and nitrogen sources and the carbon:nitrogen ratio were shown to be key factors 
Table 1 Simultaneous production of laccase and lignin peroxidase (LiP) from Streptomyces cinnamomensis by submerged fermentation

\begin{tabular}{|c|c|c|c|c|c|c|c|}
\hline \multirow[t]{2}{*}{ Run } & \multicolumn{5}{|c|}{ Medium ingredients, $\mathrm{g}^{\mathrm{a}}$} & \multicolumn{2}{|c|}{ Activity, U/mL } \\
\hline & Yeast extract & Coffee pulp & Wheat bran & Urea & Sawdust & Laccase $^{\mathbf{b}}$ & $\mathrm{LiP}^{\mathbf{b}}$ \\
\hline 1 & 2.57 & 0.84 & 0.60 & 0.71 & 0.28 & 0.0004 & 0.0032 \\
\hline 2 & 1.81 & 0.19 & 0.26 & 0.76 & 1.98 & 0.0023 & 0.0092 \\
\hline 3 & 1.37 & 0.75 & 2.20 & 0.26 & 0.42 & 0.0002 & 0.0093 \\
\hline 4 & 1.05 & 2.44 & 0.23 & 0.64 & 0.64 & 0.0060 & 0.0009 \\
\hline 5 & 0.80 & 0.43 & 2.23 & 1.45 & 0.09 & 0.0062 & 0.0070 \\
\hline 6 & 0.58 & 0.67 & 0.82 & 0.16 & 2.77 & 0.0007 & 0.0033 \\
\hline 7 & 0.39 & 1.24 & 0.09 & 2.73 & 0.55 & 0.0039 & 0.1240 \\
\hline 8 & 0.22 & 2.15 & 1.24 & 0.23 & 1.16 & 0.0041 & 0.0015 \\
\hline 9 & 0.07 & 0.09 & 1.42 & 2.09 & 1.33 & 0.0065 & 0.0001 \\
\hline Mean \pm SD & $\begin{array}{l}0.98 \\
\pm 0.81\end{array}$ & $\begin{array}{l}0.98 \\
\pm 0.83\end{array}$ & $\begin{array}{l}1.01 \\
\pm 0.82\end{array}$ & $\begin{array}{l}1.00 \\
\pm 0.90\end{array}$ & $\begin{array}{l}1.02 \\
\pm 0.88\end{array}$ & $\begin{array}{l}0.0034 \\
\pm 0.0026\end{array}$ & $\begin{array}{l}0.0176 \\
\pm 0.0400\end{array}$ \\
\hline
\end{tabular}

${ }^{\mathrm{a}}$ Basal medium for each run contained $\mathrm{CaCO}_{3}(0.02 \mathrm{~g} / \mathrm{L}), \mathrm{MgSO}_{4}(0.1 \mathrm{~g} / \mathrm{L})$ and trace element solution of $1 \%$, with veratryl alcohol (sterilized using a $1 \mathrm{mmol} / \mathrm{L}$ filter) as inducer.

${ }^{\mathrm{b}}$ Activity on the day 10 of submerged fermentation.

influencing extracellular laccase or peroxidase production from Penicillium chrysogenum [24], Streptomyces sp. F2621 and F6616 [16], Streptomyces viridosporus [25], Streptomyces albus [26], Botryosphaeria rhodina [27], Pleurotus ostreatus and Pleurotus sajorcaju [28], and Streptomyces lavendulae [5].

To verify the effect of the medium formulation on laccase and LiP activities and their activity ratio (laccase: LiP), three new medium formulations with different theoretical laccase:LiP activity ratios were designed (equations 7 to 9). For greater accuracy, the difference in variations (adjusted $R^{2}$ ) and significance levels of the regression models of Equations. 5 and 6 were taken into account and quoted as parameters when designing the new medium formulations with different laccase:LiP activity ratios.

Table 2 Solutions to the expected maxima of laccase and lignin peroxidase (LiP) activities

\begin{tabular}{lll}
\hline & Laccase & LiP \\
\hline Exp. max. activity & 0.0174 & 0.1339 \\
Component & \\
$F_{1}$ & $-4.500 \times 10^{-8}$ & $-2.700 \times 10^{-8}$ \\
$F_{2}$ & 0.2926 & 0.3132 \\
$F_{3}$ & -0.3663 & -1.5934 \\
$F_{4}$ & -0.2859 & 0.0847 \\
Ingredient & & \\
Yeast extract & 0.62 & 0.74 \\
Coffee pulp & 1.15 & 0.97 \\
Wheat bran & 0.73 & 0.19 \\
Sawdust & 0.89 & 0.61 \\
Ureaa & 1.61 & 2.49 \\
\hline
\end{tabular}

aUrea $=5$ - (yeast extract) - (coffee pulp) - (wheat bran) - (sawdust).

$$
\begin{aligned}
& 0.1 \text { laccase } 1 \mathrm{LiP}=\frac{0.1 \times \mathrm{Lac} \times \frac{0.929}{0.191}+1 \times \mathrm{LiP} \times \frac{0.978}{0.108}}{0.1 \times \frac{0.929}{0.191}+1 \times \frac{0.978}{0.108}}=0.1014+0.02806 \\
& \times \mathrm{F}_{2}-0.02769 \times \mathrm{F}_{3}+0.004633 \times \mathrm{F}_{4}-0.01380 \times \mathrm{F}_{1}^{2}-0.04481 \\
& \times \mathrm{F}_{2}^{2}-0.008870 \times \mathrm{F}_{3}^{2}-0.02806 \times \mathrm{F}_{4}^{2} \\
& 1 \text { laccase: } 1 \mathrm{LiP}=\frac{1 \times \operatorname{Lac} \times \frac{0.929}{0.191}+1 \times \operatorname{LiP} \times \frac{0.978}{0.108}}{1 \times \frac{0.929}{0.191}+1 \times \frac{0.978}{0.108}}=0.07461+0.01999 \\
& \times F_{2}-0.02004 \times F_{3}+0.002613 \times F_{4}-0.01027 \times F_{1}^{2}-0.03201 \\
& \times F_{2}^{2}-0.007530 \times F_{3}^{2}-0.02022 \times F_{4}^{2} \\
& 2 \text { laccase: } 1 \mathrm{LiP}=\frac{2 \times \mathrm{Lac} \times \frac{0.929}{0.191}+1 \times \operatorname{LiP} \times \frac{0.978}{0.108}}{2 \times \frac{0.929}{0.191}+1 \times \frac{0.978}{0.108}}=0.05948+0.01544 \\
& \times \mathrm{F}_{2}-0.01573 \times \mathrm{F}_{3}+0.001473 \times \mathrm{F}_{4}-0.008280 \times \mathrm{F}_{1}^{2}-0.02478 \\
& \times \mathrm{F}_{2}^{2}-0.006770 \times \mathrm{F}_{3}^{2}-0.01549 \times \mathrm{F}_{4}^{2}
\end{aligned}
$$

After unconstrained programming, the theoretical solutions to these three equations were calculated (Table 3).

\section{Result of verification}

For the verification experiment using SmF culture at $25^{\circ}$ $\mathrm{C}$ with shaking at $150 \mathrm{rpm}$ (Table 4), on the 14th day of $\mathrm{SmF}$ with the optimal medium (w/v) of yeast extract $1.24 \%$, coffee pulp $2.3 \%$, wheat bran $1.46 \%$, sawdust $1.78 \%$ and urea $3.22 \%$ (from Eqn 5) (Table 2; Table 4), laccase from S. cinnamomensis reached a peak of 0.0175 $\mathrm{U} / \mathrm{mL}$, which was approximately 5.1 times activity of the initial average value of $0.0034 \mathrm{U} / \mathrm{mL}$ (Table 1 ) and a little higher than the expected peak of $0.0174 \mathrm{U} / \mathrm{mL}$ (Table 2). This validated that laccase activity could be controlled by medium nutrition, and the optimized medium formulation was reliable for laccase production.

After 7 days of SmF culture using the optimal liquid medium (w/v) of yeast extract $1.48 \%$, coffee pulp 1.94\%, 
Table 3 Theoretical solutions to medium formulations designed to produce laccase-lignin peroxidase (LiP) complexes with different laccase:LiP activity ratios

\begin{tabular}{|c|c|c|c|}
\hline & \multicolumn{3}{|c|}{ Designed laccase:LiP ratio } \\
\hline & $\begin{array}{l}0.1 \text { laccase: } 1 \\
\text { LiP }^{\mathrm{a}}\end{array}$ & $\begin{array}{l}1 \text { laccase: } 1 \\
\text { LiP }^{\mathrm{b}}\end{array}$ & $\begin{array}{l}2 \text { laccase: } 1 \\
\text { LiPc }^{c}\end{array}$ \\
\hline \multicolumn{4}{|l|}{ Component } \\
\hline$F_{1}$ & $-7.800 \times 10^{-8}$ & $-5.500 \times 10^{-8}$ & $-5.400 \times 10^{-8}$ \\
\hline $\mathrm{F}_{2}$ & 0.3131 & 0.3123 & 0.3115 \\
\hline $\mathrm{F}_{3}$ & -1.5609 & -1.3307 & -1.1617 \\
\hline $\mathrm{F}_{4}$ & 0.0826 & 0.0646 & 0.0466 \\
\hline \multicolumn{4}{|l|}{ Ingredient } \\
\hline $\begin{array}{l}\text { Yeast } \\
\text { extract }\end{array}$ & 0.74 & 0.76 & 0.77 \\
\hline $\begin{array}{l}\text { Coffee } \\
\text { pulp }\end{array}$ & 0.98 & 1.01 & 1.03 \\
\hline $\begin{array}{l}\text { Wheat } \\
\text { bran }\end{array}$ & 0.2 & 0.28 & 0.35 \\
\hline Sawdust & 0.61 & 0.66 & 0.69 \\
\hline Urea $^{d}$ & 2.47 & 2.29 & 2.16 \\
\hline
\end{tabular}

${ }^{\mathrm{a}}$ Corresponding to $\max (0.1 \times$ laccase $+1 \times$ LiP $)=0.1276$.

${ }^{\mathrm{b}}$ Corresponding to $\max (1 \times$ laccase $+1 \times$ LiP $)=0.0911$.

${ }^{c}$ Corresponding to $\max (2 \times$ laccase $+1 \times$ LiP $)=0.0711$.

${ }^{\mathrm{d}}$ Urea $=5$ - (yeast extract) - (coffee pulp) - (wheat bran) - (sawdust).

wheat bran $0.38 \%$, sawdust $1.22 \%$ and urea $4.98 \%$ (Eqn 6; Table 2; Table 4), LiP from $S$. cinnamomensis reached a peak of $0.1450 \mathrm{U} / \mathrm{mL}$, which was approximately 8.2 times activity of the initial average value of $0.0176 \mathrm{U} /$ $\mathrm{mL}$ (Table 1) and higher than the expected peak of $0.1339 \mathrm{U} / \mathrm{mL}$ (Table 2). This confirmed that the LiP activity could also be controlled by medium nutrition, and the optimized medium formulation was reliable for LiP production.

After 11 days of SmF culture using the three new medium formulations designed to produce laccase-LiP complexes with theoretical activity ratios of 0.0537 to 0.1 (Eqn 7), 0.537 to 1 (Eqn 8) and 1.074 to 2 (Eqn 9)
(Table 3; Table 4), the measured activity ratios of laccase:LiP from S. cinnamomensis reached $0.1,0.41$ and 1.7 respectively (Table 5 ). The three activity ratios of laccase:LiP had nearly reached the designed levels of 0.05 to $0.1,0.54$ to 1 and 1.07 to 2 by day 11 of $\mathrm{SmF}$ fermentation, suggesting that the activity ratio between different enzymes produced simultaneously from one strain had the potential to be directly controlled by medium formulation. In addition, when the activity ratio of laccase:LiP reached the expected levels on day 11 of fermentation, the laccase or LiP activity also reached peaks (Table 5) on days 10,11 or 12 , implying that the accordance of measured and theoretical laccase:LiP activity ratio was a true result as designed.

\section{Conclusions}

Compared with strain improvement by genetic engineering [2], optimization of medium formulation is a lowcost way to control enzyme activities and their ratio. By adjusting medium formulation, we produced a crude laccase-LiP complex with designed laccase:LiP activity ratio specially for the degradation of species-specific plant lignins with fixed proportion of phenolic units to non-phenolic compounds. Using such specially designed laccase-LiP complexes, the degradation of lignin and lignocellulose biomass should be improved. By improving the biodegradation of abundant and renewable lignocellulosic biomass, laccase-LiP complex with specially designed laccase:LiP activity ratio will be beneficial to industrial processes.

\section{Methods \\ Materials}

The S. cinnamomensis strain used was obtained from BOKU University of Natural Resources and Applied Life Sciences (Vienna, Austria). Wheat bran and sawdust were purchased, and coffee pulp was obtained from a

Table 4 Designed medium formulation for the verification experiment ${ }^{a}$ by submerged fermentation of Streptomyces cinnamomensis

\begin{tabular}{|c|c|c|c|c|c|c|c|}
\hline & Expected maximum activity & Yeast extract & Coffee pulp & Wheat bran & Sawdust & Urea & Total \\
\hline Laccase & 0.0174 & $0.62^{b}(1.24 \%)^{g}$ & $1.15^{\mathrm{b}}(2.3 \%)$ & $0.73^{\mathrm{b}}(1.46 \%)$ & $0.89^{b}(1.78 \%)$ & $1.61^{b}(3.22 \%)$ & $5(10 \%)$ \\
\hline LiP & 0.1339 & $0.74^{\mathrm{c}}(1.48 \%)$ & $0.97^{\mathrm{C}}(1.94 \%)$ & $0.19^{c}(0.38 \%)$ & $0.61^{c}(1.22 \%)$ & $2.49^{c}(4.98 \%)$ & $5(10 \%)$ \\
\hline \multicolumn{8}{|c|}{ Designed laccase:LiP ratio } \\
\hline 0.1 laccase: 1 LiP & - & $0.74^{d}$ & $0.98^{d}$ & $0.20^{d}$ & $0.61^{d}$ & $2.47^{d}$ & 5 \\
\hline 1 laccase: 1 LiP & - & $0.76^{\mathrm{e}}$ & $1.01^{\mathrm{e}}$ & $0.28^{\mathrm{e}}$ & $0.66^{\mathrm{e}}$ & $2.29^{e}$ & 5 \\
\hline 2 laccase: 1 LiP & - & $0.77^{f}$ & $1.03^{f}$ & $0.35^{f}$ & $0.69^{f}$ & $2.16^{f}$ & 5 \\
\hline
\end{tabular}

${ }^{a}$ See Methods section for details.

${ }^{\text {b}}$ Solutions to max (laccase) in Table 2.

'Solutions to $\max (\mathrm{LiP})$ in Table 2.

${ }^{\mathrm{d}}$ Solutions to $\max (0.1 \times$ laccase $+1 \times$ ILiP) in Table 3 .

éSolutions to $\max (1 \times$ llaccase $+1 \times$ ILiP $)$ in Table 3 .

fSolutions to $\max (2 \times$ llaccase $+1 \times$ ILiP) in Table 3 .

${ }^{\mathrm{g}} 1.24 \%=(0.62 \mathrm{~g}$ yeast extract $) /(50 \mathrm{~mL}$ liquid medium $) \times 100 \%$, the remaining percentage data in this table was calculated similarly. 
Table 5 Measured activity ratios of laccase-LiP complexes produced from Streptomyces cinnamomensis by submerged fermentation with optimized medium formulation

\begin{tabular}{|c|c|c|c|c|c|c|c|c|c|}
\hline \multirow[t]{3}{*}{ Day } & \multicolumn{9}{|l|}{ Treatment } \\
\hline & \multicolumn{3}{|c|}{0.1 laccase/1 LiP } & \multicolumn{3}{|c|}{1 laccase/1 LiP } & \multicolumn{3}{|c|}{2 laccase/1 LiP } \\
\hline & Laccase $^{a}$ & $\mathrm{LiP}^{\mathrm{a}}$ & Laccase: LiP & Laccase $^{a}$ & $\mathrm{LiP}^{\mathrm{a}}$ & Laccase: LiP & Laccase $^{a}$ & $\mathrm{LiP}^{\mathrm{a}}$ & Laccase: LiF \\
\hline 6 & 0.0017 & 0.0016 & 1.1 & 0.0010 & 0.0058 & 0.17 & 0.0006 & 0.0035 & 0.2 \\
\hline 7 & 0.0010 & 0.0052 & 0.19 & 0.0006 & 0.0077 & 0.1 & 0.0007 & 0.0020 & 0.4 \\
\hline 8 & 0.0009 & 0.0069 & 0.1 & 0.0003 & 0.0009 & 0.3 & 0.0021 & 0.0044 & 0.48 \\
\hline 9 & 0.0019 & 0.0037 & 0.51 & 0.0004 & 0.0073 & 0.05 & 0.0008 & 0.0002 & 4 \\
\hline 10 & 0.0005 & 0.0032 & 0.2 & 0.0006 & 0.0056 & 0.1 & 0.0015 & $0.0074^{\mathrm{b}}$ & 0.20 \\
\hline 11 & 0.0007 & 0.0075 & $0.1^{c}$ & 0.0019 & 0.0046 & $0.41^{c}$ & $0.0045^{b}$ & 0.0026 & $1.7^{c}$ \\
\hline 12 & 0.0002 & $0.0114^{b}$ & 0.02 & $0.0027^{\mathrm{b}}$ & $0.0096^{\mathrm{b}}$ & 0.28 & 0.0041 & 0.0040 & 1.0 \\
\hline 13 & 0.0009 & 0.0055 & 0.2 & 0.0030 & 0.0058 & 0.52 & 0.0015 & 0.0025 & 0.60 \\
\hline Range $^{d}$ & \multicolumn{3}{|c|}{$0.0537: 1^{\mathrm{e}}$ to $0.1: 1$} & \multicolumn{3}{|c|}{$0.537: 1^{\mathrm{f}}$ to $1: 1$} & \multicolumn{3}{|c|}{$1.074: 1^{9}$ to $2: 1$} \\
\hline
\end{tabular}

${ }^{\mathrm{a} U} / \mathrm{mL}$

${ }^{\mathrm{b}}$ Activity peak of each enzyme produced using the designed medium.

${ }^{c}$ Measured activity ratios of laccase/LiP produced using the designed medium.

${ }^{\mathrm{d}}$ Theoretical scope of laccase:LiP.

${ }^{\mathrm{e}}(0.100 \times 0.929 / 0.191) /(1 \times 0.978 / 0.108)$.

$\mathrm{f}(1 \times 0.929 / 0.191) /(1 \times 0.978 / 0.108)$.

${ }^{\mathrm{g}}(2 \times 0.929 / 0.191) /(1 \times 0.978 / 0.108)$

common coffee machine in the Division of Food Biotechnolgy, Department of Food Sciences and Technology, BOKU - University of Natural Resources and Applied Life Sciences, Austria.

\section{Inoculum preparation}

To prepare the inoculum, a growth medium composed of $15 \mathrm{~g} / \mathrm{L}$ malt extract, $15 \mathrm{~g} / \mathrm{L}$ yeast extract, $0.5 \mathrm{~g} / \mathrm{L}$ $\left(\mathrm{NH}_{4}\right)_{2} \mathrm{SO}_{4}, 0.1 \mathrm{~g} / \mathrm{L} \mathrm{CaCO} 3,0.5 \mathrm{~g} / \mathrm{L} \mathrm{MgSO}_{4}$, and $0.5 \%$ $(\mathrm{v} / \mathrm{v})$ trace element solution $\left(1 \% \mathrm{FeSO}_{4}, 0.09 \% \mathrm{ZnSO}_{4}\right.$, $0.02 \% \mathrm{MnSO}_{4}(\mathrm{w} / \mathrm{v})$ and distilled water) in $250 \mathrm{~mL}$ baffled flasks was autoclaved at $120^{\circ} \mathrm{C}$ for 20 minutes, then inoculated with $S$. cinnamomensis slant. The flasks were cultured at $25^{\circ} \mathrm{C}$ with shaking at $130 \mathrm{rpm}$ for 3 days until spore concentration reached $1.5 \times 10^{7}$ colony-forming units $(\mathrm{CFU}) / \mathrm{cm}^{3}$.

\section{Experimental design and fermentation}

The medium for laccase and LiP production from S. cinnamomensis by $\mathrm{SmF}$ (Table 1) was prepared in Erlenmeyer flasks with veratryl alcohol as inducer [5,29]. After inoculation with $10 \%(7.5 \mathrm{~mL} \mathrm{v} / \mathrm{v})$ of bacterial cell suspension containing $1.5 \times 10^{7} \mathrm{CFU} / \mathrm{mL}, 75 \mathrm{~mL}$ medium from each run was cultured at were cultured at $25^{\circ} \mathrm{C}$ with shaking at 120 to $130 \mathrm{rpm}$.

\section{Laccase activity assay}

The laccase activity was determined by oxidation of 2,2'azino-bis(3-ethylthiazoline-6-sulfonate) (ABTS, Sigma Chemical Co., St Louis, MO, USA) [5], with 1 U defined as the amount of laccase oxidizing $1 \mu \mathrm{mol}$ of ABTS per minute [30].

\section{Lignin peroxidase activity assay}

LiP activity was determined spectrophotometrically [5], with $1 \mathrm{U}$ of LiP activity defined as $1 \mu \mathrm{mol}$ of veratryl alcohol oxidized in 1 minute $[5,19]$.

\section{Spore concentration assay}

Spore concentration was determined by measuring the absorbance at $650 \mathrm{~nm}$ [5]. The control had the same medium, but without inoculation.

\section{Data analysis}

To fully analyze the possible interaction among the medium ingredients, a formulation design based on uniform design $\mathrm{U}_{9}\left(3^{9}\right)$ was adopted to optimize the medium formulation with five ingredients (Table 1). Corresponding to this formulation design, a seconddegree polynomial regression model (Eqn 10) was constructed, with enzyme activity as the dependent variable [31]. After PCA, four principal components $\left(F_{1}, F_{2}, F_{3}\right.$, $\mathrm{F}_{4}$ ) corresponding to four ingredients (yeast extract, coffee pulp, wheat bran, sawdust) were constructed. Using unconstrained mathematical programming, the optimal solutions to $F_{1}, F_{2}, F_{3}, F_{4}$ were calculated when the dependents of enzyme activities reached maximum, then the optimal dosages of the four ingredients (yeast extract, coffee pulp, wheat bran, sawdust) could be calculated, and finally the optimal medium formulation could be fully calculated because the sum of five ingredients in each run was 5 , hence:

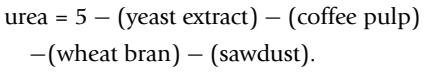


The enzyme activity model could be constructed as shown by Eqn 10:

$$
\begin{aligned}
y= & \beta_{0}+\beta_{1} \times \mathrm{F}_{1}+\beta_{2} \times \mathrm{F}_{2}+\beta_{3} \times \mathrm{F}_{3}+\beta_{4}+\mathrm{F}_{4}+\beta_{11} \times \mathrm{F}_{1}^{2}+\beta_{22} \\
& \times \mathrm{F}_{2}^{2}+\beta_{33} \times \mathrm{F}_{3}^{2}+\beta_{44} \times \mathrm{F}_{4}^{2}\left(R^{2}, \text { significance }\right)
\end{aligned}
$$

where $y$ represents laccase or LiP activity; $\mathrm{F}_{1}, \mathrm{~F}_{2}, \mathrm{~F}_{3}$ and $\mathrm{F}_{4}$ were the principal components corresponding to the four ingredients of yeast extract, coffee pulp, wheat bran and sawdust in culture medium; $\beta_{\mathrm{i}}$ was the partial regression coefficient with $\beta_{0}, \beta_{1}, \beta_{2}, \beta_{3}$ being the linear terms and $\beta_{11}, \beta_{22}, \beta_{33}, \beta_{44}$ being the quadratic terms. $R^{2}$ indicated to what extent of variability in the response could be explained by statistical model, and significance indicated the aptness of statistical model.

\section{List of abbreviations}

CFU: colony-forming unit; LiP: lignin peroxidase; PCA: principal component analysis; SmF: submerged(/liquid) state fermentation; SSF: solid-state (/substrate) fermentation.

\section{Acknowledgements}

We are grateful to all the colleagues in Division of Food Biotechnology, Department of Food Sciences and Technology, BOKU University of Natural Resources and Applied Life Sciences for their general support or technical suggestions. This research was supported by the Eusia-Pacific Uninet Scholarship Award, National Natural Science Foundation of China (grant number 30700102), Branch of the Water Pollution Control and Management Project (2008ZX07209-010), Beijing Nova Program (grant number 2008A074) and Training Fund for Talents of Beijing (grant number 2010A005016000001).

\section{Author details}

'College of Life Sciences, Capital Normal University, Beijing 100048, China. ${ }^{2}$ Division of Food Biotechnology, Department of Food Sciences and Technology, BOKU University of Natural Resources and Applied Life Sciences, Vienna A-1190, Austria. ${ }^{3}$ China Rural Technology Development Center, Beijing, 100045, China.

\section{Authors' contributions}

DJ performed the literature retrieval, experimental design, experimental operation and data acquisition, data analysis and interpretation, and drafted the manuscript and submission. JW provided technical suggestions, and participated in the manuscript preparation and submission. Both authors read and approved the final manuscript.

\section{Competing interests}

The authors declare that they have no competing interests.

Received: 17 December 2011 Accepted: 20 March 2012

Published: 20 March 2012

\section{References}

1. Martínez ÁT, Speranza M, Ruiz-Dueñas FJ, Ferreira P, Camarero S, Guillén F, Martínez MJ, Gutiérrez A, del Río JC: Biodegradation of lignocellulosics: microbial, chemical, and enzymatic aspects of the fungal attack of lignin. Int Microbiol 2005, 8:195-204

2. Masarin F, Gurpilhares DB, Baffa DCF, Barbosa MHP, Carvalho W, Ferraz A, Milagres AMF: Chemical composition and enzymatic digestibility of sugarcane clones selected for varied lignin contents. Biotechnol Biofuel 2011, 4:55.

3. Weng JK, Li X, Bonawitz ND, Chapple C: Emerging strategies of lignin engineering and degradation for cellulosic biofuel production. Curr Opin Biotech 2008, 19:166-172.
4. Francisco J, Ruiz-Dueñas FJ, Martínez ÁT: Microbial degradation of lignin: how a bulky recalcitrant polymer is efficiently recycled in nature and how we can take advantage of this. Microb Biotechnol 2009, 2(2):164-177.

5. Jing DB: Improving the simultaneous production of laccase and lignin peroxidase from Streptomyces lavendulae by medium optimization. Bioresource Technol 2010, 101:7592-7597.

6. Jing DB, Li PJ, Xiong XZ, Wang LH: Optimization of cellulase complex formulation for peashrub biomass hydrolysis. Appl Microbiol Biot 2007, 75:793-800.

7. Niladevi KN, Sukumaran RK, Prema P: Utilization of rice straw for laccase production by Streptomyces psammoticus in solid-state fermentation. J Ind Microbiol Biotechnol 2007, 34:665-674.

8. Wen XH, Jia YN, Li JX: Degradation of tetracycline and oxytetracycline by crude lignin peroxidase prepared from Phanerochaete chrysosporium-a white rot fungus. Chemosphere 2009, 75:1003-1007.

9. Zhu QS, Yan LF, Guo QX: Clean energy from biomass Beijing: Chemical Industry Press; 2002.

10. Jordaan J: Isolation and characterization of a novel thermostable and catalytically efficient laccase from Peniophora sp. strain UD4. PhD thesis Rhodes University; 2005.

11. Dubé E, Shareck F, Hurtubise Y, Daneault C, Beauregard M: Homologous cloning, expression, and characterisation of a laccase from Streptomyces coelicolor and enzymatic decolourisation of an indigo dye. Appl Microbiol Biot 2008, 79(4):597-603.

12. Bourbonnais R, Paice MG: Oxidation of non-phenolic substrates: an expanded role for laccase in lignin biodegradation. FEBS Lett 1990, 267:99-102.

13. Breen $A$, Singleton $F L$ : Fungi in lignocellulose breakdown and biopulping. Curr Opin Biotech 1999, 10:252-258.

14. Martínez ÁT, Ruiz-Dueñas FJ, Martínez MJ, del Río JC, Gutiérrez A: Enzymatic delignification of plant cell wall: from nature to mill. Curr Opin Biotech 2009, 20:348-357.

15. Singh D, Chen S: The white-rot fungus Phanerochaete chrysosporium: conditions for the production of lignin-degrading enzymes. Appl Microbiol Biotechnol 2008, 81:399-417.

16. Tuncer M, Kuru A, Sahin N, Isikli M, Isik K: Production and partial characterization of extracellular peroxidase produced by Streptomyces sp F6616 isolated in Turkey. Ann Microbiol 2009, 59(2):323-334.

17. Pandey A, Radhakrishnan S: Packed bed column bioreactor for production of enzymes. Enzyme Microb Technol 1992, 14:486-488.

18. Masurekar PS: Nutritional and engineering aspects of microbial process development. Prog Drug Res 2008, 65:293-328, 291.

19. Alam MZ, Mansor MF, Jala KCA: Optimization of lignin peroxidase production and stability by Phanerochaete chrysosporium using sewagetreatment-plant sludge as substrate in a stirred-tank bioreactor. J Ind Microbiol Biotechnol 2009, 36(5):757-764

20. Erden E, Ucar MC, Kaymaz Y, Pazarlioglu NK: New and different lignocellulosic materials from Turkey for laccase and manganese peroxidase production by Trametes versicolor. Eng Life Sci 2009, 9(1):60-65.

21. Niladevi KN, Prema P: Effect of inducers and process parameters on laccase production by Streptomyces psammoticus and its application in dye decolourization. Bioresource Technol 2008, 99:4583-4589.

22. Vikneswary S, Noorlidah A, Renuvathani M, Sekaran M, Pandey A, Jones EBG: Productivity of laccase in solid substrate fermentation of selected agroresidues by Pycnoporus sanguineus. Bioresource Technol 2006, 97:171-177.

23. Zhao J, Kwan HS: Characterization, molecular cloning, and differential expression analysis of laccase genes from the edible mushroom Lentinula edodes. Appl Environ Microbiol 1999, 65(11):4908-4913.

24. Rodriguez A, Falcon MA, Carnicero A, Perestelo F, DelaFuente G Trojanowski J: Laccase activities of Penicillium chrysogenum in relation to lignin degradation. Appl Microbiol Biotechnol 1996, 45(3):399-403.

25. Zerbini JE, Oliveira EMM, Bon EPS: Lignin peroxidase production by Streptomyces viridosporus T7A- Nitrogen nutrition optimization using glucose as carbon source. Appl Biochem Bioech 1999, 77(9):681-688.

26. Antonopoulos VT, Rob A, Ball AS, Wilson MT: Dechlorination of chlorophenols using extracellular peroxidases produced by Streptomyces albus ATCC 3005. Enzyme Microb Tech 2001, 29:62-69.

27. Dekker RFH, Barbosa AM, Giese EC, Godoy SDS, Covizzi LG: Influence of nutrients on enhancing laccase production by Botryosphaeria rhodina MAMB-05. Int Microbiol 2007, 10(3):177-185. 
28. Kurt S, Buyukalaca S: Yield performances and changes in enzyme activities of Pleurotus spp. (P. ostreatus and P. sajorcaju) cultivated on different agricultural wastes. Bioresource Technol 2010, 101:3164-3169.

29. Niladevi KN, Sheejadevi PS, Prema P: Strategies for enhancing laccase yield from Streptomyces psammoticus and its role in mediator-based decolorization of azo dyes. Appl Biochem Biotechnol 2008, 151(1):9-19.

30. Lu L, Zhao M, Zhang BB, Yu SY, Bian XJ, Wang W, Wang Y: Purification and characterization of laccase from Pycnoporus sanguineus and decolorization of an anthraquinone dye by the enzyme. Appl Microbiol Biotechnol 2007, 74:1232-1239.

31. Fang KT, Ma CX: Orthogonal and Uniform Experimental Design Beijing: Science Press; 2001.

doi:10.1186/1754-6834-5-15

Cite this article as: Jing and Wang: Controlling the simultaneous production of laccase and lignin peroxidase from Streptomyces cinnamomensis by medium formulation. Biotechnology for Biofuels 2012 5:15.

\section{Submit your next manuscript to BioMed Central} and take full advantage of:

- Convenient online submission

- Thorough peer review

- No space constraints or color figure charges

- Immediate publication on acceptance

- Inclusion in PubMed, CAS, Scopus and Google Scholar

- Research which is freely available for redistribution

Submit your manuscript at www.biomedcentral.com/submit 